\title{
PEMENUHAN ELEMEN NECESSARY CONDITIONS KECAMATAN DALAM PENYELENGGARAAN PEMERINTAHAN UMUM DI KABUPATEN PANDEGLANG
}

\section{MEETING THE ELEMENTS OF SUB-DISTRICT NECESSARY CONDITIONS IN PUBLIC GOVERNMENT IN PANDEGLANG DISTRICT}

(disubmit 23 November 2020, direvisi 05 Desember 2020, diterima 07 Desember 2020)

\author{
Arif Nugroho $^{1}$ dan Delly Maulana ${ }^{1}$ \\ ${ }^{1}$ Universitas Serang Raya, Jl. Raya Serang-Cilegon Km.5 Taman Drangong Serang Banten \\ Corresponding Author: ariyul88@gmail.com
}

\begin{abstract}
ABSTRAK
Artikel ini mengulas Pemenuhan Elemen Necessary Conditions Kecamatan dalam penyelenggaraan pemerintahan umum baik secara nasional dan spesifik diperdalam dengan fakta empiris di Kabupaten Pandeglang, hal itu sebagai konsekuansi dari pelaksanaan Undang - Undang Nomor 23 Tahun 2014. Penelitian dilakukan dengan menggunakan pendekatan kualitatif. Hasil penelitian diketahui, penyelenggaraan pemerintahan umum Kecamatan baik fakta secara nasional serta pendalaman fakta empiris di Kabupaten Pandeglang menunjukan belum cukup tertopang oleh elemen necessary condition diantaranya kepastian atas kewenangan legalnya serta anggaran yang menyertainya. Oleh sebab itu dipandang perlu ada kemauan politik baik itu dari Presiden untuk segera mengundangkan Peraturan - Pemerintah sebagai landasan teknis bagi pemerintah daerah selaku kepala wilayah maupun dari Kepala Daerah Kabupaten/Kota untuk melakukan terobosan agar supaya di masa peralihan implementasi Undang - Undang Nomor 23 Tahun 2014 kewenangan - kewenangan pada bidang kesatuan bangsa, keamanan dan keteriban umum dapat dilimpahkan pada Kecamatan serta Elemen Necessary Conditions lain yang menyertainya diperkuat.

Kata Kunci: Pemerintahan Umum, Elemen Necessary Conditions, Kecamatan
\end{abstract}

\begin{abstract}
This article discusses the fulfillment of the elements of the sub-district's necessary conditions in the administration of general government both nationally and specifically and deepened by empirical facts in Pandeglang Regency, this is a consequence of the implementation of Law Number 23 of 2014. The research approach used is qualitative. The results showed that in the administration of district general government both the facts nationally and the deepening of empirical facts in Pandeglang district were not sufficiently supported by elements of necessary conditions, including certainty of legal authority and budget. Therefore, there needs to be political will, both from the president, to immediately ratify the Government Regulation as a technical basis for the regional government (Territory) as well as from the
\end{abstract}


Jurnal Kebijakan Pembangunan Daerah, Vol.4, No.2, Desember 2020, Hal. 129 - 146

p-ISSN: 2597-4971, e-ISSN: 2685-0079

Head of Regency / City to make breakthroughs so that in the transitional period the implementation of Law Number 23 Year 2014 powers in the areas of national unity, security and public order can be transferred to the District and the accompanying elements of necessary conditions are strengthened.

Keywords: General Government, Element of Necessary Conditions, District 


\section{PENDAHULUAN}

\section{Beberapa peristiwa di Kabupaten} Pandeglang yang mana jika tidak dikelola dengan baik akan kontra produktif terhadap perwujudan cita - cita urusan Pemerintahan Umum/kesatuan bangsa serta keamanan dan ketertiban umum yakni seperti dikutip dari Bantenhits,11 November 2015, Ratusan warga Kecamatan Cadasari Kabupaten Pandeglang yang tergabung dalam jamiyatul muslimin menggelar istigasah di kawasan parkir DPRD Provinsi Banten menolak rencana didirikanya indusrti air mineral. Penolakan didasarkan atas sebuah asumsi, jika Kabupaten Pandeglang menjadi daerah industri serta destinasi urbanisasi maka potensi kemaksiatan/ pelanggaran terhadap kultur dan nilai nilai religiusitas meningkat di Kabupaten Pandeglang. Melihat kendala semacam itu tentunya dianggap oleh Pemerintah Daerah khususnya Kecamatan sebagai dilemma dan berujung pada keputus asaan. Dilema yang dimaksud yakni disatu sisi Kabupaten Pandeglang perlu mencari alternatif lain dalam menggenjot PAD (Pendapatan Asli Daerah), namun terjadi resistensi karena oleh sebagian kelompok masyarakat alternatif tersebut dianggap bertentangan dengan kultur dan nilai nilai religiusitas yang sudah menjadi primordialisme di kalangan masyarakat. Terkait dengan kondisi PAD, berdasarkan hasil pra penelitian diketahui bahwa Kabupaten Pandeglang memiliki ketergantungan yang tinggi pada pendapatan asli daerah dari sektor PBB (Pajak Bumi dan Bangunan). PBB tetap mendominasi selain penerimaan daerah dari sektor retribusi dan pajak lainya. Adapun data bahwa PAD (Pendapatan Asli Daerah) Kabupaten Pandeglang kurang lebih sebesar Rp. 197 miliar pada tahun 2017, sedangkan untuk tahun 2018 PAD Pandeglang ditargetkan meningkat menjadi sekitar Rp. 203 miliar.

Selain peristiwa itu ada lagi, misalnya yang terjadi masih di tahun 2015 lalu, Pemerintah Kabupaten Lebak yang telah melarang berbagai aktifitas Organisasi Gerakan Fajar Nusantara (GAFATAR), namun pencekalan tersebut dikawatirkan oleh MUI (Majelis Ulama Indonesia) Pandeglang jika seluruh aktifitas organisasi tersebut berpindah ke Pandeglang, alasannya karena letak yang berdekatan dan kultur yang tidak berbeda jauh dikutip Nugroho dan Maulana 2020 (Nugroho, Arif \& Maulana, Delly 2020). Selanjutnya sebagaimana dikutip dari (detakbanten.com 24 Februari 2016) dengan berita yang berjudul antisipasi konflik sara, Badan Kesatuan Bangsa dan Politik Pandeglang Gelar Rakor. Dalam 
isi berita tersebut bahwa pembentukan dan keberadaan Forum Pembaruan Kebangsaan (FPK), dibentuk untuk mengantisipasi terjadinya potensi konflik di dalam masyarakat yang disebabkan oleh masalah suku, agama dan ras. FPK telah dibentuk di 8 (delapan) Kecamatan di Kabupaten Pandeglang yakni di Kecamatan Pandeglang, Majasari, Karangtanjung, Cadasari, Labuan, Paninmbang, Cikeusik, Sumur. Langkah awal yang akan dilakkukan oleh FPK adalah melakukan pembinaan secara konsiten pada 51 orang mantan anggota GAFATAR yang telah dipulangkan ke kampung halamannya di Pandeglang.

Terkait dengan beberapa permasalahan yang telah diuraikan di paragraph pertama, Nugroho dan Maulana 2020 (Nugroho, Arif \& Maulana, Delly 2020) memetakan bahwa faktor yang dapat menghambat suksesnya desentralisasi yakni (1) campur tangan pemerintah pusat yang relatif besar terhadap pemerintah daerah atau organisasi yang berada di bawahnya (desentralisasi parsial), (2) Lemahnya struktur dan kapasitas pemerintah daerah (kapasitas kelembagaan yang ada di bawahnya) dalam menjalankan kewenangan yang diberikan kepadanya menjadi masalah lain yang juga harus mendapat perhatian, (3) Kondisi di lapangan yang relatif dinamis yang relatif berbeda antara daerah satu dengan daerah yang lainya, (4) Aktor pemerintahan yang tidak memiliki kemampuan untuk mendelegasikan, atau kekurangan kapasitas pemantauan dan penegakan yang kuat akan berubah menjadi pemain orkestra untuk mencapai tujuan mereka, (5) Pendekatan top-down mengurangi pentingnya pengambilan keputusan lokal, sehingga mengurangi keuntungan efisiensi desentralisasi, (6) desentralisasi tidak terkelola secara optimal karena office politics yang berlangsung didomain pemerintah, (7) Kurangnya pemahaman dan komitmen Kepala daerah beserta aparat birokrasi dalam memberdayakan field station di bawahnya seperti Kecamatan. Memberdayakan camat baru sampai pada tahap keinginan (good will dan political will).

Merujuk kompilasi riset seperti Kaur, Prinja, K Singh \& Kumar (2012), Nannyonjo and Okot (2013), De Smet, Peeters and Sterckx (2016). Osavelyuk, Munkueva, Tipaeva, Dorzhiev, Namzhilon. (2015). Abbott, Genschel, Zangl (2015) Landwehr and Böhm (2011). Murthy and Mahin (2015), Santoso (2010) Kemmochi, Kato, Uchium. (2016), Emerick, Mothusi \& Molaodi, (2004) alternatif yang direkomendasikan dalam mendukung 
keberhasilan dalam desentralisasi yaitu pemerintah harus ditopang oleh sistem administrasi yang kuat dan sistematis, berorientasi pada pelatihan pada struktur desentralisasi administratif dan distribusi sumber daya berbasis kinerja serta Kepemimpinan administratif yang dinamis di Kabupaten ternyata lebih efektif dan warga Negara setidaknya memiliki kewajiban untuk memilih anggota legislatif yang secara eksplisit mendukung hal tersebut, sehingga tidak ada lagi argumen politis atas kegagalan pelaksanaan delegasi kewenangan tersebut di lapangan.

Kecamatan sebagaimana diatur dalam Undang Undang Nomor 23 Tahun 2014 Tentang Pemerintahan Daerah digambarkan sebagai berikut;

\section{Penyelenggaraan Pemerintahan Daerah}

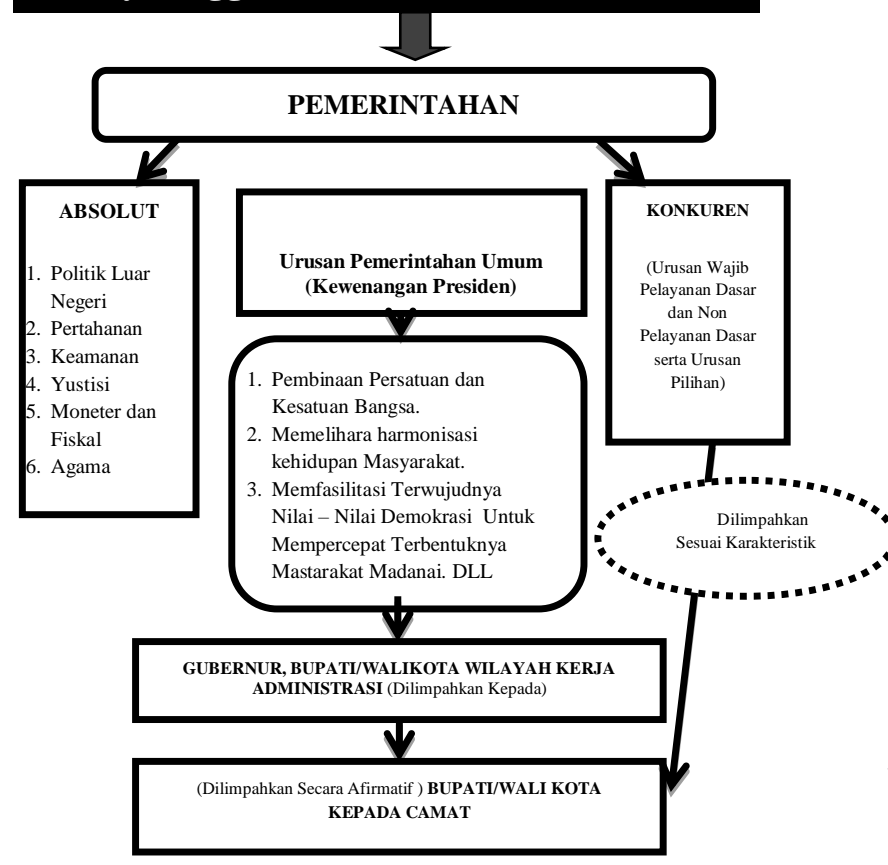

Gambar 1. Kecamatan Berdasarkan UU No 23 Tahun 2014

Sumber: Nugroho dan Maulana 2020 (2020)

Gambar. 1 dapat dijelaskan bahwa Undang - Undang Nomor 23 Tahun 2014 menjadikan berhimpitnya daerah otonom dengan wilayah administrasi. Model semacam itu seperti model yang dijelaskan oleh Fried (1963) dikutip dari Smith (1985) yakni model Integrated Perfectoral System. Posisi Kecamatan di Undang - Undang Nomor 23 Tahun 2014 merupakan birokrasi kewilayahan dalam daerah otonom yang mana dikonstruksikan sebagai perangkat wilayah administrasi penyelenggaraan pemerintahan umum. Hal yang niscaya dilakukan Kepala Daerah yakni melimpahkan

kewenangan penyelenggaraan pemerintahan umum kepada Camat. Perlu diketahui bahwa inti dari urusan pemerintahan umum adalah hal - hal yang berkaitan dengan kesatuan bangsa, keamanan dan ketertiban umum. Kondisi tersebut sebetulnya pada zaman pemerintahan kolonial Hindia Belanda pernah terjadi, Surianingrat (1981:68) imenjelaskan saat diundangkanya Reglemen 1854 susunanya distrik (wedana) mengemban tugas dan tanggung jawab dalam hal pekerjaan kepolisian, segala pekerjaan dan kekuasaan yang diserahkan kepada kepala distrik 
(wedana) menurut aturan tersebut dilakukan oleh kepala Onderdistrik). Dari histori serta uraian tersebut nampaknya Kecamatan sebagai birokrasi kewilayahan yang berada di akar rumput dianggap strategis untuk mengakomodir urusan pemerintahan umum, untuk itu efektifitasnya merupakan hal yang perlu menjadi perhatian pemerintah baik tingkat pusat maupun daerah.

Secara operasional hirarki kerja Kecamatan menurut Undang - Undang Nomor 23 Tahun 2014 berada di bawah Pemerintah Kabupaten/Kota membantu Dirjen Politik dan Pemerintah Umum Kementerian Dalam Negeri Kabupaten/Kota. Dalam hal ini Camat memiliki kewenangan secara atributif sebagai Ketua Forkopimka (Forum Koordinasi Pimpinan Kecamatan). Konsekuensi kedudukan Kecamatan sebagai perangkat wilayah administrasi penyelenggara kewenangan pemerintahan umum akan memperoleh Pendanaan dari sumber APBN (Anggaran Pendapatan dan Belanja Negara) dan pelaksanaan tugas lain dibebankan kepada yang menugasi (Presiden Sebagai Kepala Pemerintahan).

Diketahui Pemerintah tidak kunjung menetapkan PP (Peraturan Pemerintah) Tentang Pemerintahan Umum, maka artinya belum ada kepastian hukum dalam tataran operasional, untuk itu pendanaan
Camat sebagai pimpinan Forkopimka akan membebani APBD (Anggaran Pendapatan dan Belanja Daerah) Kabupaten/Kota. Di tengah terbatasnya kemampuan APBD Kabupaten/Kota, khususnya Pemerintah Kabupaten Pandeglang tetap berharap dukungan anggaran sumber APBN sesuai amanat Undang - Undang. (Wawancara Pra Penelitian dengan Kepala Bagian Tata Pemerintahan Kabupaten Pandeglang, 2017).

Beberapa kompilasi penelitian yang diuraikan sebelumnya sebagaimana dilakukan Nannyonjo and Okot (2013), Kemmochi et al (2016). Emerick et al (2004) Dharmawan (2008) dan lain sebagainya juga menjelaskan bahwa pemenuhan elemen necessary condition diperlukan guna terwujudnya efektifitas lembaga. Artikel ini mengulas tentang penyelenggaraan pemerintahan umum di Kecamatan serta pemenuhan elemen necessary condition kelembagaan Kecamatan baik secara Nasional dan secara khusus fakta empiris di Kabupaten Pandeglang, mengingat Kecamatan adalah birokrasi lokal kewilayahan di tingkat akar rumput yang merupakan daya dukung penyelenggaraan pemerintahan baik pusat maupun daerah, maka peneliti menganggap menarik untuk diulas.

\section{METODE PENELITIAN}


Penelitian dilakukan dengan menggunakan pendekatan kualitatif. Teknik pengumpulan data yang dilakukan dalam penelitian ini yaitu wawancara, telaah dokumen dan literatur. Penentuan informan menggunakan teknik purpossive sampling. Informan yang ditentukan, terdiri dari (1) Kepala Sub Bidang Bina Kewilayahan dan Kepala Sub Bidang Perundang Undangan Kementerian Dalam Negeri, (2) Guru Besar Bidang Pemerintahan Daerah Universitas Terbuka Tangerang.

Teknik analisis data dalam penelitian ini menggunakan model analisis data interaktif dari Miles, Huberman dan Saldana (2014). Penggambaran model analisis datanya dilakukan dengan langkah-langkah sebagai berikut:(1) Kondensasi data (data condensation); (2) Penyajian data (data display); (3) Penarikan kesimpulan (conclusions drawing). Teori/konsep yang dibangun diantaranya Decentralization In Cities, Decentalization Management.

\section{HASIL PENELITIAN}

Tinjauan Undang - Undang Nomor 23 Tahun 2014

\section{Mencermati Undang - Undang}

Nomor 23 Tahun 2014, lebih lanjut dalam kaitanya dengan kedudukan Kecamatan pakar Ilmu pemerintahan daerah dari
Universitas Terbuka Tangerang mengatakan;

"Kalau Kecamatan ini menurut saya menjadi semakin rancu justru itu menarik untuk diteliti. Kalau UU No 32 Tahun 2004 itu jelas jadi yang double itu provinsi sebagai wilayah administrasi dan daerah otonom, sedang kab/ kota daerah otonom sehingga perangkat yang ada di bawahnya adalah SKPD. Undang - undang 23 tahun 2014 maka Kabupaten itu double fungsi WA (Wilayah Administrasi) dan DAOT (Daerah Otonom) keliatanya menjadi begini ada OPD sebagai pengganti SKPD, adalagi ini Kecamatan ini sebagai organ dekon. Kalau Kecamatan ini disebut desentralisasi maka dia harus memperoleh penyerahan urusan pemerintahan. Kalau dulu jelas Kecamatan itu SKPD kalau sekarang Kecamatan itu disebut OPD kalau OPD itu kan perangkat daerah padahal kalau fungsinya seperti itu namanya perangkat wilayah administrasi. Harus diperhatikan Kecamatan ini beda dengan kalau di Amerika District,town, township, village district ada lagi namanya school district itu semua bukan Kecamatan, ini semua semacam Kabupaten itu menerima desentralisasi menerima penyerahan urusan pemerintahan dari state / Negara bagian. Jadi ini bukan organya town atau district ini masing masing berdiri sendiri. Dulu jaman belanda Kecamatan ini kan disebut onder district tapi permasalahanya Undang Undang hindia belanda kala itu adalah dekonsentrasi tidak sama dengan Vilage district yang ada di amerika itu. Memang Kecamatan adalah 


\begin{abstract}
perangkat dekon, ada lagi di atasnya Kecamatan yaitu kawedanan wilayahnya disebut District namun pengertian district dalam pemerintahan hindia belanda adalan pilah prestasi, sehingga dengan kondisi undang - undang saat ini diskusinya di situ. (wawancara, Desember 2017)
\end{abstract}

Ketika konsep Undang - Undang Nomor 23 Tahun 2014 mengharuskan berhimpitnya antara DAOT (Daerah Otonom) dengan WA (Wilayah Administrasi), maka memunculkan pertanyaan ketika seorang Kepala Daerah harus melakukan pengaturan kewenangan perangkatnya dalam penyelenggaraan Pemerintahan Daerah. Apakah Pengaturan yang dilakukan dalam "penyelenggaraan Pemerintahan Daerah" di dalamnya hanya terkandung makna pengaturan dalam kapasitas sebagai kepala DAOT (urusan wajib dan pilihan pemerintahan daerah) saja, ataukah kalimat "pengaturan dalam penyelenggaraan pemerintahan daerah" secara otomatis mengandung makna pengaturan dalam kapasitas yang terintegrasi yakni sebagai kepala DAOT dan WA. Semisal urusan Pemerintahan Daerah dan urusan Pemerintahan Umum yang menjadi kewenangan Kepala Daerah, dalam pelaksanaanya dapat "melimpahkan" kepada Camat. Jika melihat dari Undang - Undang sebelumnya, Undang - Undang Nomor 5 tahun 1974 sangat jelas judulnya "Pemerintahan di Daerah". Namun karena bahasa dalam Undang - Undang itu tegas maka selayaknya dalam Undang Undang Nomor 23 Tahun 2014 kalimat penyelenggaraan "pemerintahan daerah" ini perlu dimaknai bahwa kandungan di dalamnya berhimpitan antara DAOT dan WA serta urusan - urusanya. Dalam pasal 13 ayat (4) huruf a hingga b dijelaskan bahwa urusan pemerintahan yang menjadi kewenangan Kabupaten/kota adalah urusan yang lokasi dan penggunaanya, di Kabupaten/kota.

Ketika penyelenggaraan "pemerintahan daerah" ini dimaknai mengandung berhimpitannya DAOT dan WA serta urusan - urusanya, lebih lanjut berkaitan dengan perangkat daerah, jika ditinjau dari pasal 225 Undang - Undang Nomor 23 Tahun 2014, Kecamatan sebagai penyelenggara Pemerintahan Umum dan melaksanakan urusan Pemerintahan yang menjadi kewenangan Daerah Kabupaten/kota yang tidak dilaksanakan oleh unit kerja perangkat daerah Kabupaten/kota yang ada di Kecamatan. Dalam hal ini Kecamatan berkedudukan ganda sebagai perangkat wilayah administrasi penyelenggara Pemerintahan Umum dan sebagai perangkat daerah otonom. Konsekuensi dari itu, secara konseptual 
Camat/Kecamatan dituntut mampu menjadi daya dukung pencapaian tujuan penyelanggaraan pemerintahan daerah dari 32 urusan otonomi daerah dan juga tujuan penyelenggaraan pemerintahan umum.

\section{Necessary Conditions dalam}

Penyelenggaraan Pemerintahan Umum

Pandangan strategis Camat diposisikan sebagai penyelenggara pemerintahan umum Informan dari Direktorat Jenderal Politik dan Pemerintahan Umum Kementerian Dalam Negeri mengatakan;

"Sebetulnya kesbang itu enggak bisa kerja sendiri ... stakeholder dia kan polisi TNI BIN KUMHAM kejaksaan.....selama ini untuk pengawasan orang asing dengan kumham stabilitas dengan TNI informasi dengan BIN dan lainnya itu mereka dapatkan dari institusi samping dan pasti formatnya pun format terkait pertahanan keamanan dengan moneter yang absolut......Camat sebetulnya satusatunya perangkat yang bisa diandalkan gak mungkin dia mencari keseluruh Kecamatan mencari informasi nggak mungkin harusnya cukup informasi dari camat istilahnya benang jatuh di jerami pun ketika Camat mengetahui itu sampaikan dan itu informasikan dengan camat-camat yang lain yang berjalan di Kecamatan." (Wawancara,
Wawancara tersebut menjelaskan, asumsinya jika penyelenggaraan pemerintahan umum sudah berjalan secara efektif (Instansi Vertikal Direktorat Jendral Politik dan Pemerintahan Umum sudah ada di Kabupaten/Kota), satu satunya mitra yang strategis dalam bidang kesatuan bangsa yang paling strategis adalah Kecamatan. Hal itu karena Kecamatan adalah perangkat kewilayahan. Sharing informasi dengan Kecamatan - Kecamatan yang lain pun relatif mudah dengan format kesatuan bangsa, dibandingkan dengan pihak TNI (Tentara Nasional Indonesia) dan Kepolisian Republik Indonesia yang cenderung informasinya dengan format pertahanan dan keamanan.

Kondisi eksisting penyelenggaraan Pemerintahan Umum di Kabupaten/Kota dijelaskan pada gambar:

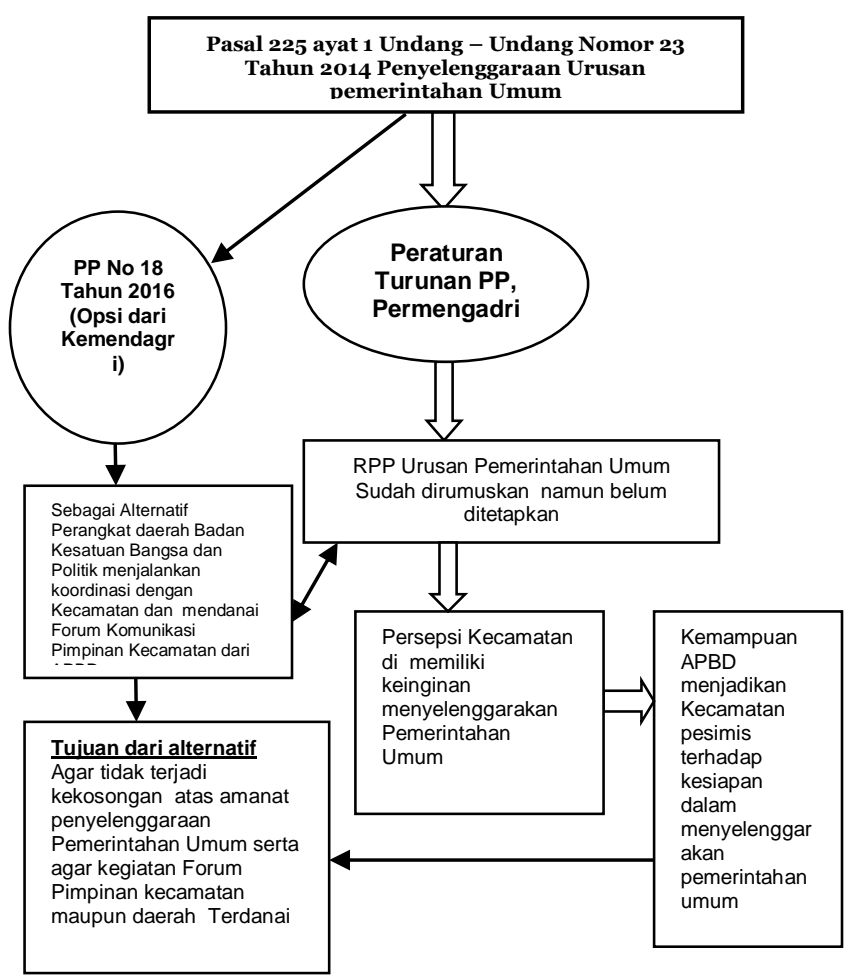


Gambar 2. Eksisting Kebijakan

Penyelenggaraan Pemerintahan Umum Sumber: Data Diolah Peneliti 2017.

Terkait dengan Gambar 2, seiring dengan diterapkanya Undang-Undang Nomor 23 Tahun 2014, dan penegasan pada Peraturan Pemerintah Nomor 17 Tahun 2018 selain terjadi perubahan fungsi dan kedudukan Kecamatan, adapun arah kebijakan yang dirumuskan dalam RPP (Rancangan Peraturan Pemerintah) Penyelenggaraan Pemerintahan Umum bahwa Kecamatan secara operasional kedudukanya membantu Pemerintah Kabupaten dan instansi vertikal Direktorat Jenderal Politik dan Pemerintah Umum Kementerian Dalam Negeri Kabupaten dalam penyelenggaraan Pemerintahan Umum, Camat secara atributif menjadi Pimpinan Forkopimka (Forum Koordinasi Pimpinan Kecamatan), kedudukan tersebut berjenjang dari tingkat Pusat, Provinsi hingga Kabupaten/kota. Dalam hal ini Camat kembali memiliki kewenangan secara atributif sebagai Forum Pimpinan di tingkat Kecamatan. Konsekuensi kedudukan Kecamatan sebagai perangkat wilayah administrasi penyelenggara urusan Pemerintahan Umum sesuai dengan Pasal 225 ayat (2) akan memperoleh Pendanaan dari sumber APBN dan pelaksanaan tugas lain dibebankan kepada yang menugasi (Presiden Sebagai Kepala Pemerintahan). Sejalan dengan itu, diketahui bahwa keberadaan RPP penyelenggaraan Pemerintahan Umum yang hingga saat ini belum disahkan oleh Presiden sehingga berkonsekuensi pada ketidak pastian mekanisme penyelenggaraan serta dukungan pendanaan yang bersumber dari APBN. Kemudian persepsi Pemerintah Kabupaten/Kota terkait dengan hal itu, pada dasarnya Pemerintah Kabupaten/kota memiliki kemauan dan keinginan mengimplementasikan penyelenggaraan Pemerintahan Umum. Namun yang menjadi permasalahan adalah kemampuan dan kesiapan ini merupakan suatu hal yang masih diperhitungkan. Mengingat pagu indikatif pada Kecamatan selama ini tergolong minim, misalnya sebagai contoh di Kabupaten Pandeglang yakni Rp 710.757.600.,00 pada tahun 2017 dan menurut informasi di daerah lain 500 juta bahkan ada yang dibawah 500 juta di tahun - tahun sebelumnya. Selain itu keterbatasan Sumberdaya manusia juga membuat pesimis urusan pemerintahan umum tersebut akan berjalan efektif jika nantinya Peraturan Pemerintah dan Permendagri (Peraturan Menteri Dalam 
Negeri) ditetapkan namun tidak diimbangi dengan alokasi anggaran khusus dari Pemerintah Pusat.

Terkait dengan perkembangan RPP (Rancangan Peraturan Pemerintah) penyelenggaraan Pemerintahan Umum, diketahui hingga saat ini RPP terkait vertikalisasi Badan Kesatuan Bangsa dan Politik dan penyelenggaraan urusan Pemerintahan Umum sudah diajukan pada Presiden, namun belum ditanda tangani. Karena ada pertimbangan kemampuan APBN yang diestimasi akan tersedot hingga 10 Triliun ketika PP (Peraturan Pemerintah) tersebut diterapkan. Sebelumnya RPP sudah masuk taraf harmonisasi di Kemenkumham (Kementerian Hukum dan Hak Asasi Manusia) dan telah diparaf oleh 4 empat Kementerian, namun setelah naik ke Presiden ada rapat terbatas di Sekretariat Kabinet dan hingga saat ini masih ditunda. Dengan belum diturunkanya peraturan tersebut, hal itu membingungkan, karena Pemerintah Daerah tidak memiliki landasan operasional. Sesuai dengan saran dari Pihak Kementerian Dalam Negeri akhirnya langkah alternatif yang diambil terutama dalam kaitanya mendanai Forkopimda dan Forkopimka adalah dari APBD sebagaimana diamanatkan dalam Peraturan Menteri Dalam Negeri Nomor
33 Tahun 2017 Tentang Pedoman Umum APBD tahun 2018. Tentunya pemecahan masalah dalam lokalitas tetap dengan payung hukum peraturan perundang udangan yang berlaku. Berkaitan dengan itu, perihal keterbatasan kemampuan APBD daerah untuk pendanaan kegiatan Forkopim baik daerah maupun Kecamatan. Informan dari Direktorat Jenderal Politik dan Pemerintahan Umum Kementerian Dalam Negeri mengatakan ; "....banyak juga camat yang konsultasi pada kita, waktu itu ada konsultasi sama kita ada lima orang ....Kalau saya paling menanyakan anggaran itu, karena koordinasi antar Polres sama Koramil kadang mereka itu beranggapan pola pikir kita itu adalah anggaran dan anggaran dulu, jeleknya di situ kalau kita bilang. Sebenarnya kalau kita kerja dengan aturan yang sudah jelas itu pasti anggarannya turun sendiri kan, karena kita kerja itu kan pakai ongkos ya, istilah jalan memantau situasi dari daerah ke daerah lain. Akhirnya kita jelaskan untuk sementara tidak bisa dianggarkan karena RPP nya tidak jadi ditandatangani oleh Presiden, sebutannya ditunda lah sampai batas waktu yang tidak bisa ditentukan. Cuma ada yang tanya “ ada kebijakan lain ga " saya bilang tidak ada. Untuk ini tidak ada karena di UU jelas, kita harus tunggu PP nya, kalau sudah ditandatangi baru bisa kita bergerak..."(wawancara, Oktober 2017).

Perihal keterbatasan kemampuan APBD daerah untuk pendanaan kegiatan 
Forum koordinasi pimpinan baik Daerah maupun Kecamatan. Rata rata Kecamatan yang berkonsultasi di Kemendagri menanyakan tentang dukungan anggaran untuk koordinasi seperti dengan Kepolisian Resor, Kepolisian Sektor dan Komando Distrik Militer. Namun dari Kemendagri menyatakan Peraturan Pemerintahnya belum turun sampai waktu yang belum bisa ditentukan dan menyarankan alternatif membiayai kegiatan Forkopimda (Forum Koordinasi Pimpinan Daerah) dan Forkopimka sementara dengan APBD. Jadi Alternatif pembiayaan dari sumber APBD adalah sebuah pilihan yang sifatnya kondisional yang didasarkan pada kemampuan APBD yang dimiliki, termasuk bagi Pemerintah Kabupaten Pandeglang. Dalam konteks Perangkat Daerah Kecamatan, dalam hal Forkopimka mau tidak mau penyelenggaraan Kecamatan pasti tetap berhubungan dan melakukan koordinasi pekerjaan yang bersinggungan dengan penyelenggaraan pemerintahan umum. Jika permasalahanya ada pada keterbatasan APBD dan pagu indikatif Kecamatan, setidaknya hal itu bisa disiasati oleh Kecamatan. Terkait dengan diketahui tidak sedikit terjadi permasalahan sosial kemasyarakatan yang merupakan domain pemerintahan umum yang secara nyata berimplikasi terhadap pembangunan misalnya Kabupaten Pandeglang yang salah satu Kabupaten di Provinsi Banten. Dari situ sebetulnya Camat - Camat di Indonesia sebagai ketua Forkopimka sedang diuji kretifitas berfikir dan bertindak dalam penerapan prinsip koordinasi, integrasi dan sinkronisasi dalam menjalankan kapasitasnya, namun di satu sisi selayaknya Kepala Daerah juga hadir untuk memberikan solusi. Informan sebagai Tokoh Masyarakat di Kabupaten Pandeglang berpandangan sebagai berikut;

“...yang saya lihat selama ini memang camat tidak pernah menjadi manusia yang papuler, karena popularitasnya kalah dengan bupati atau malah sama kepala desa, camat itu fungsinya malah lebih administratif. Camat juga perlu inovasi, ya inovasi apapun ya sesuai dengan bidang kewenanganya sehingga apa juga bisa memeberikan kontribusi yang jauh lebih baik bagi pembangunan, masyarakat dan lainya.....Artinya apa militan saja tidak cukup jika dia tidak dibekali dengan kreatifitas dan inovasi, karena apa kan kewenanganya terbatas. Camat bukan jabatan politik. Camat itu merupakan pihak yang berdampak akibat kebijakan yang salah atasanya..” (wawancara, Mei 2018)

\section{PEMBAHASAN}

Jika pelimpahan wewenang Bupati kepada Camat, didasarkan pada adanya integrasi perangkat daerah dan perangkat 
wilayah dalam kedudukan Kecamatan, Secara spesifik mempertimbangkan karakteristik, kebutuhan penguatan pelayanan dan keberadaan program nasional pada wilayah Kecamatan, Mewajibkan Camat untuk kreatif dan inovatif, Memiliki kepastian atas terpenuhinya kecukupan kelembagaan, Ada komitmen dari bupati untuk konsisten melakukan monitoring dan evaluasi kinerja kewenangan Camat. Dengan terpenuhinya aspek - aspek tersebut, maka kewenangan Camat akan terselenggara secara efektif Nugroho dan Maulana 2020 (Nugroho, Arif \& Maulana, Delly 2020). Ketika menelisik isi Undang - Undang Nomor 23 Tahun 2014, Kecamatan berkedudukan ganda yakni sebagai perangkat daerah dan perangkat wilayah administrasi penyelenggaraan pemerintahan umum. Dalam hal itu Kecamatan dituntut mampu menjadi daya dukung pemerintah daerah dalam menjalankan amanat Undang Undang. Sejalan dengan itu ketika merujuk pendapat Norton, (1994:106) tentang model decentralizations within city, dimana ia menuturkan bahwa pola decentralizations within city mengarah pada working towards a general pettern of decentralization of functions throughout the new area on the subsidiarity principle. Atau bisa diartikan bahwa unit organisasi (Kecamatan) itu aktifitasnya harus mengarah pada fungsi umum desentralisasi daerah otonom. Untuk itu Kecamatan perlu mengelola harapan publik dalam penyelenggaraan pemerintahan daerah Romzek dan Dubnick (1990), dikutip oleh Widodo (2001) menuturkan faktor kritis dalam mengelola harapan publik yakni kemampuan mendefinisikan serta mengendalikan harapan publik yang diselenggarakan, dan derajat kontrol yang dimiliki pada sejumlah harapan yang telah didefinisikan. Berkaitan dengan kedudukan ganda pada Kecamatan sebagai sub ordinat Pemeritah Daerah merupakan konsekuensi pemerintah mengatur Model hubungan dan sudut kedudukan pusat daerah layaknya Agency Model dan Partnership Model secara simultan dalam Undang - Undang. Kavanagh, (1982) bahwa 2 (dua) model hubungan antara Pemerintah Pusat dan Pemerintah Daerah Pertama Agency Model artinya bahwa Pemerintah Daerah semata-mata dianggap sebagai pelaksana oleh Pemerintah Pusat, kemudian Kedua Partnership Model artinya menekankan pada adanya kebebasan yang luas kepada Pemerintah Daerah untuk melakukan "Local Choice". Lebih operasional lagi dalam konteks Kelembagaan Kecamatan Leemans (1970) dikutip oleh Maksum 
(2014:4) ada dua model Field Administration yakni (1) Fragmented Field Administration (2) Integrated Field Administration. Kedua model tersebut dapat dioperasionalisasikan pada organisasi yang berbasis fungsi maupun kewilayahan/ teritorial. Dalam hal ini Kecamatan merupakan Integrated Field Administrationyang yang berbasis teritorial.

Camat secara atributif menjadi Pimpinan Forkopimka (Forum Koordinasi Pimpinan Kecamatan), kedudukan tersebut berjenjang dari tingkat Pusat, Provinsi hingga Kabupaten/kota. Meir (2010) Deconcentration transfers central government authority to lower levels within ministries. However, deconcentration also includes enabling provincial and district level bureaucracies to work closely with other sub-national groups within a democratic framework. Kecamatan sebagai perangkat wilayah administrasi penyelenggara urusan Pemerintahan Umum sesuai dengan Pasal 225 ayat (2) akan memperoleh Pendanaan dari sumber APBN. Hasil penelitian menunjukan bahwa hingga peneliti berada di lapangan, karena belum ditetapkanya peraturan turunan oleh Pemerintah dalam penyelenggaraan Pemerintahan umum, maka yang terjadi adalah tidak adanya kepastian Sumber pendanaan dalam penyelenggaraan pemeritahan umum Nannyonjo and Okot (2013), Kemmochi et al (2016). Emerick et al (2004), Dharmawan (2008) sepakat bahwa dalam mewujudkan efektifitas kelembagaan diperlukan pemenuhan elemen necessary condition. Pemerintah pusat dalam hal ini Kementerian Dalam Negeri dalam masa transisi yang kurang progresif tersebut memberikan advice kepada daerah untuk mensiasati pendanaan dari APBD dalam pendanaan Forkopim baik di tingkat Kabupaten/kota maupun Kecamatan. Burn et al, (1994) (decentralization within cities) disebut lingkungan desentralisasi, kemudian Muluk, (2009:62) bahwa dalam hal ini konsep otonomi daerah merupakan wewenang untuk mengatur urusan pemerintahan yang bersifat lokalitas menurut prakarsa sendiri berdasarkan aspirasi masyarakat setempat, dengan begitu baik masyarakat dan birokrasi penyelengaraan Pemerintahan Daerah setempat untuk dapat memecahkan berbagai masalah dan pemberian layanan yang bersifat lokalitas demi kesejahteraan masyarakat yang bersangkutan. Faktanya beberapa daerah salah satunya yakni Kabupaten Pandeglang memiliki dalih keterbatasan kemampuan APBD. Jika APBD yang jadi masalah, langkah terbaik yang tetap harus 
dilakukan dalam rangka melaksanakan amanat Undang - Undang atau minimalnya esensi yang menjadi tujuanya, Kecamatan bisa saja melakukan siasat - siasat. Rondinelli, (1983:19) dikutip dari Pitono, (2012: 5) bahwa field administration, pejabat lapangan diberi keleluasaan untuk mengambil keputusan seperti merencanakan, membuat keputusankeputusan rutin, dan menyesuaikan pelaksanaan kebijakan pusat dengan kondisi setempat. Hasil penelitian menunjukan tidak sedikit terjadi permasalahan sosial kemasyarakatan terjadi, yang mana itu domain dari kewenangan penyelenggaraan pemerintahan umum Kecamatan. Intinya dengan kondisi yang seperti itu Camat sedang dituntut kreatifitasnya bagaimana caranya dengan keterbatasan sumber daya yang ada namun mampu menangani semaksimal mungkin. Terkait dengan itu kalau merujuk apa yang dijelaskan oleh Burns, et al. (1994 : 81-189), unit organ kewilayahan dalam daerah otonom secara spesifik lebih mengarah pada decentralized management,

\section{KESIMPULAN DAN SARAN}

Diketahui landasan operasional Pemerintahan umum belum ditetapkan Presiden, yang mana di dalamnya menyangkut aspek operasionalisasi dan kepastian dukungan anggaran sumber APBN. Beberapa alternatif ditawarkan oleh Kementerian Dalam Negeri yakni mengalokasikan dari APBD. Fakta yang terjadi daerah merasa besaran APBD tidak mampu mengakomodir urusan Pemerintahan Umum. Dengan kondisi seperti itu sebagian besar Kepala Daerah Kabupaten/Kota termasuk di Kabupaten Pandeglang belum mengambil langkah apapun. Seharusnya daerah memiliki inovasi dalam rangka menjalankan amanat penyelenggaraan Pemerintah Umum, hal itu bisa dilakukan seperti halnya membagi kewenangan serta anggaran Perangkat Daerah Badan Kesatuan Bangsa Dan Politik untuk sebagian kewenanganya diselenggarakan Kecamatan, namun jika kondisi ketidak pastian tersebut berlarut larut, maka akan muncul label Pemerintah Pusat yakni Presiden tidak mendukung pelaksanaan amanat Undang - Undang Nomor 23 Tahun 2014.

Sebetulnya yang dibutuhkan adalah komitmen dari Kepala Daerah termasuk di Kabupaten Pandeglang, dalam masa peralihan ini, saat Pemerintah Pusat belum memberikan kepastian hukum khususnya dalah hal anggaran sumber APBN dalam penyelenggaraan Pemerintahan Umum, seyogyanya Kepala Daerah Kabupayen/Kota khususnya di 
Kabupaten Pandeglang perlu menggambil langkah/ terobosan agar hal - hal yang terkait kesatuan bangsa, keamanan dan ketertiban umum sebagaimana esensi dari urusan Pemerintahan Umum dapat diselenggarakan oleh Kecamatan. Adapun skenario yang dapat ditempuh yakni membagi kewenangan Perangkat Daerah yang selama ini melaksanakan urusan kesatuan bangsa, keamanan dan ketertiban umum. Alasan utama harus disegerakan bahwa berdasarkan kajian dari Kementerian Dalam Negeri, Kecamatan dianggap simpul yang berkecenderungan lebih dekat dengan terjadinya berbagai permasalahan yang berkaitan dengan kesatuan bangsa, keamanan dan ketertiban umum di lingkungan masyarakat/ di wilayah kerja Camat.

\section{REFERENSI}

Abbott, Kenneth W.et al, (2015). Two Logics of Indirect Governance: Delegation and Orchestration. British Journal of Political Science / FirstView Article / July 2015, pp 1 - 11 DOI: 10.1017/S0007123414000593, Published online: 21 July 2015

Bantenhits, 11 November 2015. Ulama, Santri dan Masyarakat Banten Tolak Investor Air Minum PT Tirta Fresindo Jaya. diperoleh 18 September 2017 dari, http://www.tangeranghits.com
Burns, Danny, et.al., (1994). The Politic of Decentralization, Revitalising Local Democracy. Hongkong : MacMillan.

Detakbanten, 24 Februari 2016. Antisipasi Konflik SARA, Kesbangpol Pandeglang Gelar Rakor. diperoleh 18 September 2017 dari,https://www.detakbanten.co $\mathrm{m} /$ Pandeglang/7111-antisipasikonflik-sara-kesbangpolPandeglang-gelar-rakor

Dharmawan, Hadi, A, (2008). Reposisis Ketata Pemerintahan Kecamatan. Bogor : Pusat Studi Pembangunan Pertanian dan Pedesaan.

Emerick, Mayer N, et, al., (2004). DecentralisationOf Service Delivery As Adopted By The Central District Counsil At Bostawa. Journal Public Administration \& Development; Aug 2004; 24, 3; ABI/INFORM Collection pg. 225.

Kavanagh, Dennis, (1982). Kebudayaan Politik. Cetakan Pertama. Jakarta : Penerbit PT. Bina Aksara.

Kemmochi, Mai, et al. (2016). Research Concerning The State of Decentralization Within Cities and The Participation In City Planning . Journal of the City Planning Institute of Japan, Vol.51 No.3, October, 201

Landwehr, Claudia dan Bohm, Katharina, (2011). Delegation and Institutional Design in 
Health-Care Rationing. Journal Governance, Volume 24, Issue 4, pages 665-688, October 2011

Maksum, Irfan Ridwan, (2014). Pemerintahan Umum Berbasis Dekonsentrasi. Jakarta : Jurnal Ilmu Pemerintahan Edisi 44 Tahun 2014

Manmeet Kaur et al., (2012). Decentralization of health services in India: barriers and facilitating factors. WHO SouthEast Asia Journal of Public Health 2012;1(1):94-104

Meir, Ben, Yossef, (2010), "Morocco's Regionalization "Roadmap" and the Western Sahara". Ifrane : Al Akhawayn University, Journal On World Peace Vol. XXViI NO. 2 June 2010

Miles,M.B, Huberman, A.M, dan Saldana,J. (2014). Qualitative Data Analysis, A Methods Sourcebook Edition 3. USA : Sage Publications.

Muluk, M.R. Khairul, (2009), Peta Konsep Desentralisasi dan Pemerintahan Daerah. Surabaya : ITS Press

Murthy, Sharmila, L dan Mahin, Maya, J. (2015). Constitutional Impediments to Decentralization in The World'S Largest Federal Country. Duke Journal of Comparative \& International Law Vol. 26:79
Nannyonjo, Justine dan Okot Nicholas. (2013). Decentralization, Local Government Capacity and Efficiency of Health Service Delivery in Uganda. Journal of African Development Spring 2013 | Volume 15 \#1

Norton, Allan, (1994). International Handbook of Local and Regional Government, A Comparative Analysis of Advenced Democracies, Adwarad Elgar, UK.

Nurcholis, Hanif, (2016). Pemerintahan Daerah Moderen Akan Manpu Meningkatkan Sumber daya Daerah Di Era Masyarakat Ekonomi Asean. Pidato Pengukuhan Guru Besar. Tangerang Selatan: Tidak Diterbitkan

Osavelyuk, A. Mikhailovich, et al, (2015). Theoretical Base of Delegation of Some State Authority of Territorial Entities of the Russian Federation to Local SelfGovernment Bodies. Mediterranean Journal of Social Sciences MCSER Publishing, Rome-Italy Vol 6 No 5 S3 September 2015

Peraturan Menteri Dalam Negeri Nomor 33 Tahun 2017 , tentang Pedoman Umum APBD ( Anggaran Pendapatan dan Belanja Daerah) Tahun 2018 
Nugroho, Arif \& Maulana, Delly. (2020).

Kecamatan

Dalam

Penyelenggaraan Pemerintahan

Daerah. Serang: CV.AA.Rizky. http://repository.fisipkum.unsera.i d/51/

Pitono, Adi. (2012). Asas Dekonsentrasi dan Asas Tugas Pembantuan dalam Penyelenggaraan Pemerintahan. Jurnal Kebijakan Publik, Volume 3, Nomor 1, Maret 2012, hlm. 1-55.

Santoso, Purwo, (2010). Satu Dekade Separuh Jalan Proses Desentralisasi, Jurnal Desentralisasi. Vol 8. No 5, 2010

Smith, Brian, C, (1985). Decentralization Teritorial Dimension of The State. Masyarakat ilmu Pemerintahan IPDN, 2012

Surianingrat, Bayu , (1981), Desentralisasi dan Dekonsentrasi Pemerintahan Indonesia, Jilid I, Dewaruci Press, Jakarta,

Undang - Undang Nomor 23 Tahun 2014, tentang Pemerintahan Daerah.

Widodo, Joko, (2001). Good Governance. Jakarta : Insan Cendekia. 